\title{
PESAN DALAM TARIAN TOPENG PANJI CIREBON
}

\author{
Oleh: \\ Genik Puji Yuhanda \\ Dosen Program Studi Hubungan Masyarakat Politeknik LP3I Bandung
}

\begin{abstract}
ABSTRAK
Topeng Panji Cirebon merupakan jenis topeng yang ditarikan di awal pertunjukan, namun paling sulit ditarikan. Gerak dan musiknya sangat berlawanan. Gerak yang banyak diamnya, statis dan monoton, namun musiknya yang cepat dan keras, membuat jenis topeng ini memiliki keistimewaan tersendiri. Oleh karena itu, hanya sedikit dalang topeng Cirebon yang dapat mempertunjukkan tarian ini kepada penontonnya.

"Pesan Dalam Tarian Topeng Panji Cirebon", adalah judul dari skripsi, yang dipilih atas dasar keunikan seperti yang telah disebutkan di awal. Pertunjukan tari topeng Panji Cirebon mempunyai daya tarik tersendiri, karena di dalamnya terdapat pesan-pesan moral yang disampaikan kepada umat manusia untuk direnungkan dan diaplikasikan pada kehidupan sehari-hari. Masalah yang ingin diketahui lebih jauh dari topeng Panji Cirebon, dapat diidentifikasi dalam bentuk pertanyaan: 1) Bagaimanakah topeng Panji Cirebon dimaknai sebagai suatu pesan yang diungkapkan melalui gerak dan musik dalam konteks kehidupan masyarakat Cirebon? dan 2) Bagaimana pesan moral itu disampaikan melalui topeng Panji Cirebon?. Kedua permasalahan tersebut sama lain berkaitan sehingga dapat mengungkap pesan dalam tarian topeng Panji Cirebon.

Di dalam membahas kedua permasalahan tersebut di atas sudah barang tentu memerlukan berbagai disiplin ilmu dan pendekatan teoritis. Oleh karena itu, pendekatan etnografi digunakan sebagai perangkat yang dipandang dapat mengungkapkan permasalahan di atas tadi. Pendekatan etnografi merupakan salah satu perangkat yang di dalamnya dapat mengungkapkan aspek pesan dalam tarian topeng Panji Cirebon, karena memerlukan keterampilan untuk mengkaji bahasa atau pesan sebagai budaya dari suatu masyarakat (masyarakat Cirebon).

Berdasarkan hasil analisis, maka dapat disimpulkan bahwa pesan dalam tarian topeng Panji Cirebon, yang diungkapkan melalui gerak dan musiknya, memiliki makna-makna luhur dalam kehidupan manusia. Pesan-pesan moral di dalamnya dianjurkan agar dapat dilakukan oleh umat manusia pada kehidupan sehari-hari, sehingga kebahagiaan dan keselamatan akan datang bagi orang yang melaksanakan ajaran tersebut. Pesan-pesan dalam tarian topeng Panji Cirebon tidak lain berasal dari pedoman hidup umat Islam, yaitu Al-Qur'an dan AsSunnah.
\end{abstract}

Kata kunci: tarian, topeng, panji, Cirebon. 


\section{Pendahuluan}

Komunikasi adalah "transmisi informasi, gagasan, emosi, keterampilan, dengan menggunakan simbol-simbol, kata-kata, gambar, figur, grafik, dan sebagainya. Tindakan atau proses transmisi itulah yang biasanya disebut komunikasi”. (Berelson dan Steiner, dalam Mulyana, 2002: 62).

Sementara itu, pendapat lain mengemukakan:

Pesan merupakan seperangkat simbol verbal atau nonverbal yang mewakili perasaan, nilai atau gagasan. Pesan mempunyai tiga komponen, yaitu makna, simbol yang digunakan untuk menyampaikan makna, dan bentuk organisasi pesan. Simbol terpenting adalah kata-kata (bahasa), yang dapat mempresentasikan objek (benda), gagasan, dan perasaan, baik ucapan (percakapan, wawancara, diskusi, ceramah dan sebagainya) ataupun tulisan (surat, esai, artikel, novel, puisi, pamflet, dan sebagainya). Kata-kata memungkinkan kita berbagi pikiran dengan orang lain. Pesan juga dapat dirumuskan secara nonverbal, seperti melalui tindakan atau isyarat anggota tubuh (acungan jempol, anggukan kepala, senyuman, tatapan mata, dan sebagainya), juga melalui musik, lukisan, patung, tarian. (Lasswell, dalam Mulyana, 2002: 63).

Kita mempersepsi manusia tidak hanya lewat bahasa verbalnya, bagaimana bahasanya (halus, kasar, intelektual, dan sebagainya), namun juga melalui perilaku nonverbalnya. Pentingnya pesan nonverbal ini, misalnya dilukiskan frase, "bukan apa yang ia katakan, melainkan bagaimana ia mengatakannya". Lewat perilaku nonverbalnya, kita dapat mengetahui suasana emosional seseorang, apakah ia sedang bahagia, bingung, atau sedih. Kesan awal kita pada seseorang sering didasarkan perilaku nonverbalnya, yang mendorong untuk mengenalnya lebih jauh.

Secara sederhana, pesan nonverbal adalah semua isyarat yang bukan kata- kata:

Komunikasi nonverbal mencakup semua rangsangan, (kecuali rangsangan verbal) dalam suatu setting komunikasi, yang dihasilkan oleh individu dan penggunaan lingkungan, mempunyai nilai pesan potensial bagi pengirim atau penerima. Jadi, defenisi mencakup perilaku yang disengaja ataupun tidak sebagai bagian dari 
peristiwa komunikasi secara keseluruhan. Kita mengirim banyak pesan nonverbal tanpa menyadari bahwa hal tersebut bermakna bagi orang lain. (Samovar dan Porter, dalam Mulyana, 2002:308).

Beberapa subkultur tari dan musik menunjukkan kekhasan perilaku nonverbal penari atau penyanyinya ketika mereka sedang menari atau menyanyi. Bahasa tubuh penari yang menarikan tari Bali sangat khas, sekhas bahasa tubuh penari India ketika menarikan tari India. Bahasa tubuh penyanyi dangdut banyak menggoyangkan pinggul. Sama halnya, dengan pesan yang terkandung dalam tarian topeng Panji Cirebon, yakni dilihat dari bahasa tubuhnya, mengisyaratkan bahwa tariannya memiliki karakteristik yang lemah lembut, tidak banyak bergerak dan tingkat kesulitannya yang cukup tinggi. Sementara itu, pesan moral yang terkandung dalam tarian topeng Panji Cirebon, ialah mengharuskan manusia untuk bertingkah laku baik, sopan santun, lemah lembut dalam bertutur kata, serta berbudi luhur.

Berdasarkan tradisi Jawa, pertunjukan topeng itu diciptakan oleh Sunan Kalijaga, putra Bupati Tuban yang sangat gemar akan kesenian dan akhirnya menjadi salah seorang wali penyebar agama Islam di Pulau Jawa. Ketika pusat pemerintahan berpindah dari Jawa Timur ke Jawa tengah dan para raja memeluk agama Islam, pertunjukan topeng terlempar dari dalam istana dan kembali dipelihara oleh rakyat jelata yang belum sepenuhnya melepaskan kepercayaan asli mereka. "Dengan melihat kenyataan ini, Sunan Kalijaga memanfaatkan pertunjukan topeng (dan wayang kulit) yang digemari rakyat sebagai alat memberikan penerangan dan penyebaran agama Islam kepada rakyat banyak itu". (Sal Murgiyanto: 1980:52-53).

Namun, kini topeng Cirebon tidak lagi digunakan sebagai alat penyebaran agama Islam seperti zaman Sunan Kalijaga. Topeng Cirebon, kini lebih mengarah kepada kesenian dan kebudayaan tradisional Indonesia yang perlu dilestarikan, bukan lagi sebagai alat penyebaran agama Islam. Umat Islam sendiri di Indonesia merupakan yang terbesar di seluruh dunia. Oleh karena itu, rasanya tidak tepat, topeng Cirebon dikatakan sebagai alat penyebaran agama Islam saat ini. Toto Amsar Suanda (wawancara, 25 Mei 2007), sebagai salah satu ahli dan pemerhati topeng Cirebon, mengatakan bahwa "topeng Cirebon merupakan Qur'an yang ditarikan. Artinya, tarian topeng Cirebon memiliki makna dan pesan-pesan yang terdapat di dalam Al-Qur'an”.

Topeng Cirebon, baik itu yang meliputi Panji, Pamindo, Rumyang, Tumenggung dan Klana dapat dijadikan sebagai ajang promosi kota Cirebon. Bahkan topeng Cirebon telah dianggap oleh para seniman di Indonesia mampu mempromosikan kota Cirebon, sekaligus 
memperkenalkan Indonesia dengan kebudayaan tradisionalnya yang tidak dimiliki bangsa lain. Topeng Cirebon juga telah merambah hingga ke mancanegara seperti Amerika, Belgia, Belanda, Italia, Perancis, Kanada, New Zealand, Jepang, dan negara-negara lainnya.

Kegiatan promosi ini, sangat mendapat respon positif dari kalangan masyarakat luar negeri. Mereka beranggapan, bahwa kesenian yang dimiliki kota Cirebon ini, memiliki keunikan tersendiri, sehingga menimbulkan rasa keingintahuan untuk mengenalnya lebih dalam lagi. Toto Amsar Suanda mengatakan "Kami sering mengadakan festival ke luar negeri, dengan harapan untuk memperkenalkan kesenian topeng Cirebon dapat diterima dengan baik oleh masyarakat mancanegara. Ternyata hal tersebut benar adanya, sehingga kegiatan ini merupakan salah satu bentuk promosi kota Cirebon, lebih jauh lagi mengharumkan nama bangsa di masyarakat internasional”. (Wawancara, 24 Juli 2007).

"Di Cirebon para dalang (penari) topeng menganggap dirinya keturunan Pangeran atau Sunan Panggung, putra Sunan Kalijaga yang bukan saja menaruh perhatian terhadap seni topeng tetapi juga menarikannya sendiri”. (Sal Murgiyanto: 1980:53). Makna sebuah kesenian bisa berubah sesuai dengan zamannya dan sesuai dengan orang yang memaknainya. Pemaknaan itu juga akan sangat tergantung kepada tujuan orang yang memberi makna itu. Demikian halnya dengan topeng Cirebon. Maknanya berubah dari kepercayaan lama, Hindu-Budha dan kemudian Islam. Namun, perubahan itu hanyalah menyangkut paham sesuai dengan alam pikirannya masing-masing, sedangkan intinya sama.

Konsep pemikiran lama dalam topeng Cirebon, kemudian beralih pada konsep pemikiran Islam yang diprakarsai oleh para waliyullah. Peralihan itu tidak serta merta menghapus konsep awalnya, karena para wali pada saat itu sadar betul bahwa mereka adalah sekelompok minoritas. Untuk kepentingan penyebaran paham baru (agama Islam) mereka perlu menyesuaikan dirinya dengan kondisi dan paham mayoritas. Oleh sebab itu, wayang dan topeng dipilih sebagai media untuk penyebaran Islam tanpa menghancurkan paham dan konsep lamanya. Paham inilah yang kemudian jauh lebih dikenal daripada terdahulunya.

Kearifan para wali seperti itu, tentu saja mengundang simpati dan bahkan dukungan masyarakat, sehingga akhirnya banyak yang masuk Islam. Metode dakwah yang disampaikannya bukanlah metode kekerasan melainkan metode kedamaian. Seni wayang dan topeng dipilih dengan alasan, selain seni tersebut amat digemari masyarakat juga untuk menjaga ketenteraman masyarakat yang sudah terbina. 
Topeng Cirebon, dalam konteks kehidupan masyarakat Cirebon, mempunyai peranan yang sangat penting. Masyarakat dan khususnya kalangan seniman Cirebon mempercayai, bahwa topeng diciptakan oleh Sunan Kalijaga, dulunya merupakan media dalam rangka penyebaran agama Islam di Jawa Barat, khususnya di daerah Cirebon.

"Beberapa pertunjukan rakyat termasuk topeng, telah dimanfaatkan oleh Sunan Kalijaga sebagai alat dalam rangka menyebarluaskan agama Islam. Wali itu sendiri tampil membawakan pertunjukannya seperti di Pajajaran”. (Suryaatmadja, 1980:31). Di Cirebon, khususnya dikalangan seniman, penari topeng itu disebut dalang. Dalang topeng sama artinya dengan penari topeng. Mereka memang tak biasa menyebut penari dan tari. Penari mereka sebut dalang dan tari disebut joged Demikian pula kata topeng, artinya bukan penutup muka, seperti yang diterangkan dalam kamus besar bahasa Indonesia. Topeng sebagai penutup muka disebutnya kedok.

Dalam pertunjukkan topeng Cirebon (Topeng Dinaan), ada lima kedok pokok yang ditarikan secara berurutan menurut karakteristiknya masing-masing. Kelima kedok pokok itu ialah, Panji, Pamindo, Rumyang, Tumenggung dan Klana. Di samping itu ada juga beberapa kedok bodor seperti Jinggananom (yang nantinya berperang dengan Tumenggung Mangangdiraja), Pentul dan Tembem.

Kelima kedok tersebut, kecuali Jinggananom, berbicara kepada kita banyak hal, terutama tentang kehidupan alam semesta yang makro dan mikro (kehidupan kita sendiri). Tentu saja kita bisa menafsirkannya sendiri sesuai dengan kemampuan masing-masing. Susunan penyajian topeng Cirebon secara umum dimulai dari topeng Panji, Pamindo, Rumyang, Tumenggung dan Klana. Namun di beberapa tempat ada yang mengakhirkan topeng Rumyang. Berikut adalah perbedaan susunan penyajian dan karakteristik masingmasing dari topeng Cirebon.

\begin{tabular}{|l|l|l|}
\hline NO. & \multicolumn{1}{|c|}{ POLA PENYAJIAN I } & \multicolumn{1}{c|}{ POLA PENYAJIAN II } \\
\hline 1. & Panji & Panji \\
\hline 2. & Pamindo/Samba & Pamindo/Samba \\
\hline 3. & Rumyang & Tumenggung \\
\hline 4. & Tumenggung & Klana \\
\hline 5. & Klana & Rumyang \\
\hline
\end{tabular}

Jika susunan ini dibaca dari arah kiri ke kanan atau dari atas ke bawah, maka ia akan bermakna sebagai siklus kehidupan manusia. Siklus yang dimaksud adalah lahir, 
dewasa dan mati, atau gambaran dari tingkat nafsu manusia yakni sawwiyah, lawwamah, amarah dan mutmainah. Berikut akan dijelaskan mengenai keempat nafsu manusia sebagai berikut:

"Sawiyah yaitu nafsu yang keluar dari hidung, artinya bila sudah kepegang ilmunya Panji maka harus dikembangkan. Lawwamah yaitu nafsu dari mulut ada pada kedok Patih atau Tumenggung. Amarah yaitu nafsu yang keluar dari telinga. Ini adalah nafsu kemarahan adanya pada kedok Klana, lebih mencintai yang sifatnya dunia, kecantikan luar semata, maka hidungnya dibuat panjang, itu menandakan hidungnya orang gila perempuan atau hidung belang. Mutmainah yaitu nafsu yang keluar dari hati, sifatnya angen-angen, nafsu hati paling suci, paling berikut rohaninya dan jasmaninya. Nafsu mutmainah adalah yang dapat menjunjung tinggi derajat manusia sedangkan ke-empat nafsu yang lain adalah nafsu yang dapat menghancurkan manusia karena keluarnya dari jasmani manusia". (Royani, dalam Kartika, 1999:50).

Namun sebaliknya, jika susunan penyajian itu dibaca dari arah kanan ke kiri atau dari bawah ke atas, maka makna yang muncul adalah tingkatan hidup manusia, yakni syariat, hakekat, tarekat dan marifat. Topeng Panji menggambarkan manusia yang baru lahir. Gerakan tarinya senantiasa kecil, lembut dan halus. Langkahnya minimalis dan lebih banyak diam. Kedoknya yang berwarna putih dengan hiasan yang amat sederhana, menggambarkan kesucian, sesuci bayi. Ia tidak perlu dirias, mukanya dibiarkan alami. Panji adalah nafsu mutmainah, nafsu yang bersifat membimbing dan menyucikan serta menuntun salik. Satusatunya topeng yang mengandung kontras, adalah gambaran seseorang yang sudah mampu mengendalikan hawa nafsu, tidak tergoda dengan segala yang bersifat keduniaan. Manusia marifat adalah insan kamil, yang tindak-tanduknya tidak akan goyah sedikit pun ketika menghadapi cobaan atau mendapat anugrah dari Allah. Dia tetap tenang dan tawakal. Manusia marifat selalu sadar, bahwa gerak dan usik serta nafasnya semua tergantung Allah. Pasrah dan ikhlas adalah ciri kehidupan tingkat marifat.

Topeng Panji berwarna putih. Matanya liyep, pandangannya merunduk dan senyumnya dikulum. Raut wajahnya (wanda) menunjukkan seseorang yang alim, tutur katanya lemah lembut dan gerakannya halus. Dalam topeng Cirebon kedok ini ditarikan berkarakter alusan (halus) seperti halnya tokoh Arjuna dalam cerita wayang. Tariannya menggambarkan seseorang yang berbudi luhur, penuh kesabaran dan tahan atas segala godaan. Ini tercermin dari iringannya yang bertolak belakang (kontras) dengan tariannya. Tari topeng Panji adalah tarian paradoks. Bagi kebanyakan penonton awam, tarian ini termasuk yang paling tidak disukai karena gerakannya minim dan bukan karena gambaran kehalusan 
Dalam satu tarian topeng Panji Cirebon, penarinya dapat memperagakan dalam durasi yang berbeda-beda. Penari topeng atau yang biasa disebut dalang, ada yang menarikan topeng Panji selama 15 menit, 45 menit, bahkan hingga satu jam. Dalang topeng yang menarikan topeng Panji Cirebon selama 15 menit, hanya mempersingkat gerakan tariannya atau meminimalisnya. Sedangkan durasi tarian selama 45 menit, tidak mengubah makna tariannya, namun hanya memperbanyak gerakan yang sama dengan arah yang berbeda. Begitu juga durasi hingga satu jam, dalang topeng menarikannya dengan memperbanyak gerakannya, bisa tiga atau empat kali lipat dari durasi terpendeknya (15 atau 45 menit).

Topeng Pamindo ditarikan pada kesempatan kedua. Warnanya putih dengan hiasan yang melingkar di atas dahinya. Di tengahnya terdapat hiasan kembang tiba dan pilis yang melingkar di pipinya. Matanya liyep, hidungnya sedikit mendongkak dan mulutnya sedikit menganga, seperti seseorang yang tengah tertawa cengengesan. Kedok ini berkarakter genit atau lincah. Gerakannya gesit dan menggambarkan seseorang yang tengah beranjak dewasa, periang dan penuh suka cita.

Topeng Rumyang sewanda dengan Pamindo, namun tanpa hisan rambut. Dari dahinya melingkar hiasan pilis sampai pipi bagian bawah. Warnanya merah jambu, tetapi ada juga yang berwarna coklat muda. Karakter tarinya termasuk yang lincah, namun lebih lamban dari gerakan Pamindo. Gerakan tarinya menggambarkan seseorang yang penuh kehati-hatian dan terkesan ragu-ragu. Di Cirebon, kata Rumyang berarti ramyang-ramyang, yang artinya mulai terang. Ini gambaran seseorang manusia yang mulai mengenal kehidupan.

Topeng Tumenggung sering disebut juga kedok Patih. Kedok ini selalu dicat dengan warna yang gelap, coklat muda atau merah muda. Wandanya menyiratkan seseorang yang pemberani dan berwibawa. Matanya agak melotot, berkumis dan berjambang. Tariannya berkarakter gagah dengan gerakan-gerakan tegas sebagai gambaran seseorang yang berpangkat dan mempunyai kekuasaan.

Topeng Klana umumnya dicat warna merah. Melihat perangainya sudah dapat ditebak, bahwa kedok ini berkarakter gagah dan kasar. Matanya terbelalak, berkumis tebal dan berjambang. Keistimewaan dari Tari Topeng Klana adalah, menggambarkan seseorang yang bertabiat buruk, namun tariannya justru banyak yang disenangi penonton.

\section{Metode dan Teknik Penelitian}


Berikut ini akan dipaparkan secara singkat pengertian dari pendekatan kualitatif dan metode etnografi.

\section{Penelitian Kualitatif}

Penelitian kualitatif adalah:

Penelitian yang bersifat empiris (dapat diamati dengan pancaindera sesuai dengan kenyataan), hanya saja pengamatan atas data bukanlah berdasarkan ukuran-ukuran matematis yang terlebih dulu ditetapkan peneliti dan harus dapat disepakati (direplikasi) oleh pengamatan lain, melainkan berdasarkan ungkapan subjek penelitian, sebagaimana yang dikehendaki dan dimaknai oleh subjek penelitian. Pendekatan kualitatif menggunakan konsep kealamiahan (kecermatan, kelengkapan, atau orisinalitas) data dan apa yang sebenarnya terjadi di lapangan. Pendekatan kualitatif terutama layak untuk menelaah sikap atau perilaku dalam lingkungan yang agak artifisial, seperti dalam survei atau eksperimen. Peneliti kualitatif lebih menekankan proses dan makna ketimbang kuantitas, frekuensi atau intensitas (yang secara matematis dapat diukur), meskipun peneliti tidak mengharamkan statistik deskriptif dalam bentuk distribusi frekuensi atau presentase untuk melengkapi analisis datanya. (Mulyana, 2007:11)

\section{Metode Etnografi}

Etnografi merupakan pekerjaan mendeskripsikan suatu kebudayaan termasuk di dalamnya kesenian. Menurut Spradley metode ini ialah sebagai berikut:

Tujuan utama aktifitas ini adalah untuk memahami suatu pandangan hidup dari sudut pandang penduduk asli, sebagaimana dikemukakan oleh Bronislaw Malinowski, bahwa tujuan etnografi adalah "memahami sudut pandang penduduk asli, hubungannya dengan kehidupan, untuk mendapatkan pandangannya mengenai dunianya". Oleh karena itu, penelitian etnografi melibatkan aktifitas belajar mengenai dunia orang yang telah belajar, melihat, mendengar, berbicara, berpikir, dan bertindak dengan cara yang berbeda. Jadi, etnografi tidak hanya mempelajari masyarakat, tetapi lebih dari itu. Etnografi belajar dari masyarakat. (Spradley, 2007: $4)$.

Sementara itu, Spradley mengemukakan langkah-langkah yang ditempuh dalam penelitian etnografi meliputi hal-hal sebagai berikut:

Langkah I, yakni menetapkan informan, tujuannya:

1. Untuk mengidentifikasi beberapa karakteristik dan informan yang baik.

2. Untuk menemukan informan yang sebaik mungkin dalam mempelajari keterampilan wawancara dan melakukan penelitian etnografi.

Langkah II, yakni mewawancarai informan, tujuannya:

1. Untuk mengidentifikasi unsur-unsur dasar dalam wawancara etnografis.

2. Untuk memformulasikan dan menggunakan beberapa macam penjelasan etnografis.

3. Untuk melakukan wawancara praktis.

Langkah III, yakni membuat catatan etnografis, tujuannya: 
1. Untuk memahami sifat dasar catatan etnografis.

2. Untuk menyusun buku catatan penelitian lapangan.

3. Untuk melakukan kontak dengan seorang informan dan melakukan wawancara pertama.

Langkah IV, yakni mengajukan pertanyaan deskriptif, tujuannya:

1. Untuk melaksanakan etnografis pertama.

2. Untuk memahami proses perkembangan hubungan dengan informan.

3. Untuk mengumpulkan sampel dari percakapan informan dengan mengajukan pertanyaan-pertanyaan deskriptif.

Langkah V, yakni melakukan analisis wawancara etnografis, tujuannya:

1. Untuk memahami sifat dasar analisis etnografis.

2. Untuk mempelajari bagaimana tercita dengan simbol-simbol budaya

3. Untuk memulai suatu analisis domain dengan melakukan pencarian suatu domain pendahuluan.

Langkah VI, yakni membuat analisis domain, tujuannya:

1. Untuk memahami sifat dasar hubungan semantik serta peran hubungan itu dalam pembuatan suatu analisis domain.

2. Untuk mengidentifikasi langkah-langkah dalam menjalankan analisis domain.

3. Untuk melakukan analisis domain sistematis terhadap semua data yang terkumpul sekarang.

4. Untuk memasukkan satu atau dua pertanyaan struktural ke dalam wawancara etnografis.

Langkah VII, yakni mengajukan pertanyaan struktural, tujuannya:

1. Untuk mengidentifikasi berbagai jenis pertanyaan struktural.

2. Untuk mempelajari menggunakan pertanyaan struktural dalam etnografi.

3. Untuk menguji domain-domain yang telah dihipotesiskan dan menemukan istilah-istilah tercakup yang lain untuk domain-domain itu dengan mengajukan pertanyaan-pertanyaan struktural.

Langkah VIII, yakni membuat analisis taksonomik, tujuannya:

1. Untuk memilih suatu fokus yang bersifat sementara untuk membuat analisis mendalam.

2. Untuk memahami berbagai taksonomi rakyat dan bagaimana taksonomi itu mengorganisir domain.

3. Untuk mempelajari bagaimana membuat analisis taksonomik.

4. Untuk membangun suatu taksonomi rakyat untuk satu domain atau lebih dengan mengikuti langkah-langkah dalam mengerjakan analisis taksonomik.

Langkah IX, yakni mengajukan pertanyaan kontras, tujuannya:

1. Untuk memahami prinsip-prinsip penemuan utama dalam studi makna budaya.

2. Untuk mempelajari cara-cara untuk menemukan berbagai kontras atau perbedaan diantara berbagai simbol budaya.

3. Untuk memformulasikan dan menggunakan berbagai pertanyaan kontras.

Langkah X, yakni membuat analisis komponen, tujuannya:

1. Untuk memahami peran analisis komponen dalam studi sistem makna budaya.

2. Untuk mengidentifikasi langkah-langkah dalam membuat analisis komponen.

3. Untuk melakukan analisis komponen yang sistematik pada satu rangkaian kontras atau lebih.

4. Untuk menggunakan pertanyaan kontras untuk membuktikan dan melengkapi analisis komponen.

Langkah XI, yakni menemukan tema-tema budaya, tujuannya: 
1. Untuk memahami sifat dasar tema-tema dalam sistem makna budaya.

2. Untuk mengidentifikasi beberapa strategi membuat suatu analisis tema.

3. Untuk melaksanakan suatu analisis tema pada suasana budaya yang sedang dipelajari.

Langkah XII, yakni menulis suatu etnografi, tujuannya:

1. Untuk memahami sifat dasar penulisan etnografis sebagai bagian dari proses penerjemahan.

2. Untuk mengidentifikasi tahap-tahap yang berbeda dalam penulisan etnografi.

3. Untuk mengidentifikasi langkah-langkah dalam melaksanakan suatu etnografi.

4. Untuk menulis suatu etnografi. (Spradley, 2007:65-70).

Teknik pengumpulan data dalam penelitian ini menggunakan teknik observasi partisipan, studi kepustakaan, studi dokumentasi, dan wawancara mendalam.

\section{Hasil Penelitian dan Pembahasan}

Sebagian dalang topeng Cirebon mengatakan, bahwa Panji berasal dari kata siji (bahasa Jawa Cirebon) yang artinya satu atau kesatu. Sesuai dengan pernyataan tersebut, maka salah satu ahli topeng Cirebon mengatakan "Panji diartikan sebagai yang pertama, sebab kata Panji berasal dari siji (satu). Diartikan pertama sebab di dalam pertunjukan topeng Cirebon, topeng Panji merupakan tarian yang mengawali pertunjukannya". (Suanda, 1989:16). Hal ini boleh jadi sebuah arti yang disesuaikan dengan susunan penyajian topeng Cirebon itu sendiri yang menempatkan tari topeng Panji pada urutan pertama. Namun, makna yang lebih dalam sebenarnya tidaklah sesederhana itu. Topeng Panji, seperti telah dikatakan di atas, mengandung unsur paradoks. Ia adalah ekspresi lembut sekaligus juga keras. Unsur paradoks ini sebagai gambaran Dewa Syiwa yang di dalam agama Hindu diyakini sebagai dewa pencipta dan sekaligus pemusnah.

Koreografi topeng Panji juga paradoks karena merupakan kumpulan dari keempat tari topeng lainnya. Di dalamnya terdapat gerakan-gerakan Pamindo, Rumyang, Tumenggung dan Klana. Itu pulalah mengapa topeng ini oleh mereka disebut sebagai seri-nya topeng, karena ia merangkum gerakan keempat topeng lainnya. Topeng Panji digambarkan sebagai seseorang yang suci dan jauh dari perbuatan dosa. Sifatnya yang penuh dengan kelembutan membuat semua orang menghormati dan menghargainya. Ia lahir ke dunia seperti bayi yang tanpa membawa dosa.

Berlawanan dengan topeng Panji adalah topeng Klana, yang menggambarkan manusia dengan segala keserakahannya, serta penuh dengan perbuatan yang merugikan orang lain. Hal tersebut diterangkan pula dalam pernyataan sebagai berikut: 
Topeng Panji menggambarkan manusia yang baru lahir ke dunia. Tari topeng Panji adalah gambaran dari seorang bayi yang tak berdaya. Gambaran itu dinyatakan oleh gerakan-gerakan tarinya yang kecil-kecil dan banyak diam. Nampaknya dari gerakan itulah mengapa tari topeng Panji digambarkan sebagai seorang manusia yang baru lahir. Begitulah mereka menggambarkan tari topeng Panji. Perbedaan gambaran tari yang ada pada dasarnya tergantung dari tafsiran mereka masing-masing, dan perbedaan itu sah adanya. (Suanda, 1989:16).

Sesuai dengan kedoknya yang berwarna putih polos, topeng ini menggambarkan manusia yang bersih hatinya atau suci dari dosa. Tanpa dihias dengan warna lainnya, topeng Panji menandakan gambaran karakter dari seorang manusia yang apa adanya dan hidup dalam kesederhanaan. Jika kita melihat pada bentuk matanya yang liyep (sipit), topeng ini melambangkan insan yang penuh dengan keramahan. Artinya, sopan santun dalam pergaulan hidup manusia terdapat dalam karakter topeng ini. Mata sipit atau liyep dalam topeng Panji, mengingatkan kita terhadap seseorang yang sedang berdoa. Orang yang sedang berdoa, selalu memejamkan matanya.

Topeng Panji dengan matanya yang sipit, menggambarkan pribadi yang pasrah dan selalu menggantungkan segala urusan hidupnya kepada Yang Maha Kuasa. Lain halnya, jika kita melihat seseorang yang menunjukkan dengan mata melotot. Hal tersebut, dapat diartikan dengan sikap seseorang yang selalu menantang kepada siapa pun. Seseorang yang memandang dengan mata melotot, tentunya kita beranggapan sebagai pribadi yang berbahaya, karena sikap arogannya tidak akan disenangi oleh banyak orang. Mata melotot juga dapat diartikan sebagai orang yang sedang marah. Selain itu, ia dianggap sebagai manusia yang diktator, selalu memerintah dan berbuat dengan sewenang-wenang, yang merugikan banyak pihak. Topeng dengan ciri-ciri seperti ini, terdapat pada topeng Klana, yang menggambarkan pribadi jahat dan sering berbuat sekehendak hati, sehingga orang lain merasa terdzalimi.

Di dalam kehidupan, Allah SWT telah menciptakan segala sesuatunya dengan berpasang-pasangan. Ada siang dan malam, bulan dengan bintang, baik- buruk, dan sebagainya. Maka, penulis merasa perlu untuk menjelaskan secara singkat mengenai topeng Klana, yang memiliki karakter manusia yang berkepribadian buruk, sebagai suatu perbandingan dengan topeng Panji (yang memiliki sifat-sifat mulia).

Berbicara mengenai perangainya topeng Panji, kita teringat akan perilaku atau akhlak Nabi Muhammad SAW, yang tidak ada tandingannya dengan siapa pun. Rasulullah SAW, merupakan pribadi yang mulia bagi semua umat manusia. Tidak hanya Islam, tetapi beliau 
mengajarkan kepada siapa pun pentingnya menjaga akhlak setiap individu. Rasulullah SAW juga adalah seorang yang murah senyum, seperti yang diriwayatkan dalam Hadist Riwayat Ahmad, yakni “Abdullah bin Al-Harits bin Jaz' berkata, “Tidak pernah kulihat seorang pun yang lebih sering tersenyum daripada Rasulullah SAW." (Iman, 2004:93). Lebih lanjut lagi diceritakan, bahwa Rasulullah SAW tertawa bersama anakanak, seperti dalam Hadist Riwayat Ahmad berikut ini:

Sa'id bin Abi Rasyid meriwayatkan, bahwa suatu hari, Ya'la Al-Amiri keluar bersama Rasul Saw untuk menghadiri sebuah perjamuan. Di perjalanan, Rasulullah Saw menghampiri Husain yang sedang bermain bersama beberapa orang anak sebayanya. Beliau hendak meraihnya, namun di sana-sini ada bocah yang memeganginya. Rasulullah pun menertawakan mereka sebelum akhirnya beliau memangku Husain. Beliau meletakkan salah satu tangannya di bawah tengkuk Husain dan satunya lagi di bawah dagunya. Lalu beliau menciuminya. Beliau berkata, "Husain adalah bagian dariku, dan aku bagian dari Husain. Allah mencintai orang yang mencintai Husain. Husain adalah cucuku”.(Iman, 2004:94).

Dari penjelasan di atas, kita dapat memahami bahwa begitu pentingnya mencontoh dan memiliki akhlak seperti Rasulullah Saw, agar kehidupan sehari- hari yang dijalani mendatangkan manfaat bagi diri pribadi dan umumnya seluruh manusia. Akhlak atau karakter yang dimiliki topeng Panji, tak lain adalah warisan dari Rasulullah Saw itu sendiri. Topeng Panji yang dibawakan oleh Sunan Kalijaga, yang didalamnya terdapat sifat-sifat mulia, datang melalui sebuah insprirasi dari Rasulullah Saw sendiri. Artinya, Sunan Kalijaga menciptakan kesenian tari topeng Panji, yang didalamnya memiliki sifat-sifat luhur manusia pun mengacu pada akhlak yang dicontohkan oleh Rasulullah Saw.

\section{Makna Gerak dan Musik Topeng Panji Cirebon}

Dalam pandangan orang awam, topeng Panji seringkali dianggap kurang menarik karena gerakannya yang banyak diam, statis dan tidak energik. Gerakan topeng Panji yang lebih banyak diamnya merupakan dari karakternya sendiri. Karakter atau sifatnya yang menunjukkan seorang yang sabar dan memiliki budi pekerti yang luhur, ditampilkan dalam tarian yang tidak menuntut banyak gerak. Hal senada sesuai dengan pernyataan seperti yang diterangkan di bawah ini:

Kedok ini berwarna putih... menunjukkan seseorang yang alim, tutur katanya lemahlembut dan gerakannya halus. Dalam topeng Cirebon kedok ini ditarikan dalam karakter alusan (halus) seperti halnya tokoh Arjuna dalam cerita wayang. Tariannya menggambarkan seseorang yang berbudi luhur, penuh kesabaran dan tahan atas segala godaan.

(Sumardjo,

2002:13). 
Dalam pertunjukan topeng Cirebon saat ini, beberapa grup topeng bahkan secara sengaja tidak menampilkan topeng ini, kemudian menggantinya dengan tarian lain yang mereka sebut dengan serimpi (tarian yang diperagakan oleh wanita), di luar jenis topeng Cirebon. Penampilan topeng Panji juga seringkali lepas dari perhatian penontonnya, karena tarian ini disajikan paling awal (pagi hari) saat para penonton belum banyak yang berdatangan. Bahkan bagi penari dan nayaganya, topeng Panji seolah-olah dianggap sebagai ritus bagi mereka sendiri. Ada kesan tersendiri bagi penabuh gamelan atau nayaganya, dalam mengiringi tarian topeng Panji Cirebon. Hal ini mudah dipahami jika mengingat arah pergerakan atau berdirinya penari yang lebih sering membelakangi penonton.

Penari topeng Panji lebih sering menghabiskan arah geraknya ke arah para nayaga. Dengan kata lain, tari topeng Panji ialah peragaan yang dalang topengnya tidak ingin diperhatikan oleh penontonnya. Ketidaktertarikan para penonton pada dasarnya semata-mata disebabkan karena gerakannya yang minim dan bukan karena maknanya yang luhur itu. Topeng Panji sebenarnya adalah inti dari gerakan-gerakan tari topeng lainnya. Secara konstektual pendapat ini diperkuat dengan pernyataan "semua gerakan yang ada dalam topeng Panji merupakan induknya gerak-gerak tari yang ada dalam tarian yang lainnya, seperti Pamindo, Rumyang, Tumenggung, Patih dan Klana”. (Sujana dan Yusuf, dalam Kartika, 1999:37).

Dari kelima tarian topeng Cirebon yang tersebar di berbagai daerah, tari topeng Panji paling menunjukkan kesamaan, baik dilihat dari segi koreografi maupun musiknya. Paradoks, yakni kontras antara gerakan dan musik, serta ke- diam-an geraknya, adalah ciri utama dari tari topeng ini. Di kalangan dalang topeng Cirebon, dari kelima tarian yang ada, tari topeng Panji dianggap serinya. Artinya yang utama. Bahkan di dalam sistem pewarisan yang berlaku di kalangan dalang topeng Cirebon, tarian ini dipelajari paling akhir. Alasannya antara lain dikatakan bahwa tarian ini paling sukar, bukan karena gerakannya yang sederhana, akan tetapi karena cara menarikannya yang memerlukan kekuatan dan kesabaran. Tarian topeng Panji Cirebon diibaratkan seseorang yang sedang melaksanakan shalat. Dalam shalat, seseorang harus menyingkirkan segala permasalahan duniawinya. Artinya, yang diingat hanya Allah SWT saja, sedangkan permasalahan duniawi harus disingkirkan sejauh mungkin. Kita juga dapat melihat bahwa orang yang sedang melaksanakan shalat, gerakannya teratur, tidak terpengaruh oleh gangguan apa pun. Selain itu, gerakannya pelan, penuh penghayatan dan sangat tidak dianjurkan untuk shalat dengan 
tergesa-gesa. Shalat juga merupakan aktifitas yang telah diatur sedemikian rupa, sehingga semua orang Islam di dunia ini, melakukannya dengan gerakan yang sama.

Begitu juga dengan tari topeng Panji Cirebon, yang gerakannya tidak terpengaruh oleh musiknya. Musiknya yang berirama cepat, diibaratkan sebagai gejolak hati, sedangkan gerakannya, dianggap orang yang sedang melaksanakan shalat dengan khusyu, dan tidak terpengaruh oleh hal-hal apa pun. Menarikan topeng Panji, maka seseorang harus menahan segala hawa nafsu yang ada, serta melawan keinginan hatinya, sehingga setiap gerakannya tidak terpengaruh oleh irama musiknya yang cepat. Pernyataan yang telah dikemukakan di atas, dipertegas kembali, seperti pada kutipan berikut ini:

Seseorang yang menarikan tari topeng Panji harus sudah mampu menahan gejolak bathinnya, menahan hawa nafsu, menahan badan dan seluruh tubuhnya untuk tidak terbawa oleh arus irama musik. Ia harus mengorbankan segala keinginan bathinnya, dan nafsunya agar sampai pada tujuan yang sebenarnya. Seperti halnya dalam shalat, kita harus menutup mata, telinga dan tidak boleh banyak gerak kecuali gerak yang sudah digariskan dalam tata cara shalat. Maksudnya supaya kita khusyuk, dan apabila kita khusyuk maka yang kita rasakan adalah seperti bertemu dengan Allah dan berbicara kepada-Nya lewat doa-doa kita. Dengan itu pula kita akan merasakan kepasrahan diri yang total, bahwa kita tidak punya daya dan upaya, Allah-lah Yang Maha Kuasa atas segala-galanya. (Kartika,1999:54).

Di dalam praktiknya, tarian ini senantiasa ditarikan berlama-lama dengan cara merendahkan diri, menarik berat badan ke bawah seperti seseorang yang tertarik oleh gravitasi bumi. Kunci kekuatannya berada pada lutut penari. Selain itu, nafas penari pun senantiasa diatur sedemikian rupa sehingga di kala menari, perut penari tidak kelihatan kembung-kempis. Untuk teknis seperti ini, mereka menyebutnya dengan istilah megeng nafas (menahan nafas). Penari harus dapat mengekspresikan tarian ini seperti orang yang "mati tapi hidup, hidup tapi mati."

Gending (musik) pengiringnya yang bernama Kembang Sungsang adalah yang paling rumit dibandingkan dengan gending pengiring tari topeng lainnya. Irama musiknya bercampur-baur antara lambat dan cepat. Pada bagian-bagian tertentu, musiknya seringkali ditingkahi dengan nyanyian dan “teriakan" (senggak) para nayaga. Sepintas seperti sebuah keadaan yang riuh-rendah dan hiruk-pikuk. Musiknya sendiri, tidak memiliki makna apa pun, hanya sebagai pengiring ketika topeng Panji ditarikan atau diperagakan. Keterkaitan antara musik dan gerakan tarinya tersebut, merupakan hal yang tidak dapat dipisahkan, karena telah menyatu sebagai suatu kesatuan yang utuh. Gerakan dalam tari topeng Panji tidak seluruhnya memiliki makna, ada beberapa gerakan saja yang dapat 
dimaknai sebagai suatu pesan ditujukan kepada manusia untuk direnungkan dan diaplikasikan dalam kehidupan sehari-hari.

(1). Gerak telungkup/menekung sambil duduk dan di depannya terdapat kotak kedok sebagai tempat penyimpanannya. Gerakan ini menggambarkan manusia yang masih dalam kandungan ibunya. Menurut Rasinah, dalang topeng Cirebon, pada saat ini dalang topeng mulai membacakan atau mengucapkan mantera- mantera. Hal tersebut dihubungkan dengan tari topeng Panji sebagai gambaran manusia yang baru lahir ke dunia. Artinya, bayi yang lahir ke dunia dengan keadaan masih suci dari dosa. Keadaannya menggambarkan manusia yang tidak berdaya. Adapun mantera yang dibaca ialah:

Sumerah maring Allah Sakapindo
maring Rasulullah Kang anane
ning wetan Sinuhun Gunung Jati
Kang sume kang ana Gunung Jati
Nyi Rengge Asmara
Kang anama Sang Hyang Permana
Kang ana ing kulon
Sang Tunggul Putih
Kang anama Kesamadtullah
Kula titip pandita 40
Kang asih nikmat ning badan Kula
titip maring Abdulmutalib Cuan
lamun ora dijaga bendung Kenang
bendunge Allah Ta'ala Allahuma
bisrokhman
Mil suci saking umat Kangjeng
Nabi Muhammad Allahuma
Sotiamin
Nyuwun ning Pangeran Bonang
Pangeran Panggung minta diraksa
Sajabane sejerone panggung

Dari mantera yang disebutkan di atas, dapat kita artikan sebagai suatu bentuk kepasrahan diri kepada Allah SWT. Bentuk kepasrahan diri tersebut, dapat dilihat dalam kalimat pertama. Kemudian mantera lainnya diperuntukkan kepada Sunan Panggung atau yang lebih dikenal dengan sebutan Sunan Kalijaga, agar ia dijaga pada saat menari atau tidak menari.

"Mantera ini membantu daya tahan dan kekuatan dalam menarikan tarian- tariannya yang banyak dan berlangsung satu hari penuh. Kenyataannya mereka mampu menari sepanjang hari, bahkan ketika baru saja menderita sakit. Ada juga yang mampu menari sambil "tidur" di pentas (di luar kesadaran)". (Sumardjo, 2002:30). 
(2). Gerak memasang kedok. Gerak ini dilakukan oleh dalang topeng di awal pertunjukannya, dengan cara memasangkan topeng atau kedok (dalam bahasa masyarakat Cirebon) secara perlahan-lahan, disertai dengan kain selendang sedikit menutupinya. Gerakan ini diartikan sebagai gambaran lahirnya bayi manusia ke alam fana ini. Oleh karena itu, ki dalang pemegang kecrek (salah satu alat musik yang digunakan dalam pertunjukan tari topeng Cirebon), berbicara monolog. Di dalam masyarakat Cirebon, jika terdapat bayi yang baru lahir, maka akan digebrag (dikagetkan) dengan membunyikan benda-benda seperti piring, wajan, panci, atau rantang. Tujuannya agar bayi tersebut tidak mudah kaget atau kelak di kemudian hari memiliki jantung yang sehat. Kebiasaan ini, merupakan tradisi atau budaya dari masyarakat Cirebon yang telah mengakar kuat hingga zaman sekarang. Budaya ini diwariskan secara turun temurun kepada generasi berikutnya, dan akan tetap ada. Hal tersebut merupakan sifat budaya di dalam suatu daerah yang sulit untuk dilunturkan, karena masyarakat dalam kebudayaan tersebut, telah menganggap sebagai sesuatu yang harus dilestarikan, yang merupakan bagian dari keyakinan kelompok tertentu.

(3). Gerak tumpang tali. Gerakan ini, mengaitkan atau mempersatukan tali (dalam hal ini selendang) secara bersamaan. Gerakan ini dapat diartikan sebagai gambaran hidup bahwa di dunia ini tidak selalu berada dalam kesenangan saja, melainkan kesedihan dan kekurangan dapat terjadi pada semua manusia. Hal tersebut, harus kita pahami sebagai upaya untuk menerima apa adanya atas yang diberikan Allah SWT kepada manusia. Sikap pasrah menerima ketentuan Allah SWT, disertai dengan rasa ikhlas, akan mendatangkan kebahagiaan di kemudian hari. Oleh karena itu, jika kita ditimpa dengan musibah atau kesulitan lainnya, maka segera serahkan segala sesuatunya kepada Allah SWT, disertai dengan usaha semaksimal mungkin, sehingga kebahagiaan yang kita dambakan akan mudah diraih. Lebih dari itu, doa merupakan unsur yang tidak boleh dikesampingkan, karena jika usaha semaksimal mungkin tanpa dibarengi dengan doa, semuanya akan sia-sia saja.

(4). Gerak cantel, berarti menggambarkan bahwa individu dengan yang lainnya harus saling bersahabat. Cantel artinya "menyangkutkan dari benda yang satu ke benda lainnya". (Kamus Besar Bahasa Indonesia, 1989:150). Gerak cantel pada topeng Panji ini, dikatikan antara jari telunjuk kanan ke jari telunjuk kiri. Kita teringat dengan kata cantel, yakni pada kehidupan masa kecil bermain anak-anak. Ketika itu, jika seorang teman bermusuhan dengan kita, kemudian terjadi perdamaian diantara keduanya, maka saling cantel dilakukan guna menghubungkan tali persahabatan kembali. Namun, cantelan pada kehidupan bermain anak- 
anak, yakni saling mengaitkan jari kelingking ke jemari teman yang sebelumnya bermusuhan.

(5). Gerak olah sikut. Gerak ini meluruskan kedua tangan dari sikut hingga ke pergelangan tangan, dilanjutkan dengan gerakan ke bawah, yakni mencantelkannya atau mempersatukan jari jemari, baik tangan kiri dan kanan hingga kuat. Gerak ini melambangkan pendirian seorang manusia yang teguh pada prinsip kebenaran. Tidak takut terhadap gertakan manusia yang mengancam kepada dirinya untuk berpihak kepada kebathilan. Namun, prinsip atau keyakinan dalam memperjuangkan kebenaran, harus disertai dengan hati nurani dan perasaan, selain akal manusia.

(6). Gerak mengolah kedua tangan di samping kedua telinga atau disebut dengan gerak tempel jamang. Gerak seperti ini, diibaratkan orang yang sedang melaksanakan shalat, dengan diawali gerakan takbiratul ikhram. Gerakan ini mengisyaratkan agar manusia, khususnya umat Islam, senantiasa melaksanakan shalat lima waktu dalam sehari.

\section{Makna Busana Topeng Panji Sebagai Unsur Pendukung}

Sementara itu, unsur pendukung dalam tarian topeng Cirebon lainnya ialah terdapat pada segi busananya, selain dari gerak dan musiknya. Dalam hal ini, penulis hanya akan memaparkan secara singkat mengenai busana tari topeng Cirebon, yang tidak dapat dipisahkan dalam pertunjukan topeng Cirebon, sebagai unsur pendukung. Untuk pakaian atau kostum topeng Panji Cirebon, sebenarnya perlengkapan dalam tarian ini sama dengan tarian lainnya, seperti Pamindo, Rumyang, Tumenggung dan Klana. Artinya, apa pun tariannya, kostum atau pakaiannya adalah sama.

Tidak ada perbedaan dalam mengenakan busana, walaupun jenis tarian yang ditampilkan berbeda. Jadi, kostum keseluruhan dalam tari topeng Cirebon digunakan untuk menampilkan unsur seni yang lebih indah. Perlu diketahui sebelumnya, yakni bahwa busana tari topeng Cirebon, terdiri dari sobrah, selendang, dan kain penutup badan. Mariah mengatakan "pakaian tari topeng Cirebon digunakan untuk keperluan penutup aurat. Selain itu, yang lebih utama unsur keindahan dijadikan sebagai kreatifitas dalam menumbuhkan ketertarikan terhadap penontonnya". (Wawancara, 2 Juli 2007).

Menarik untuk kita teliti, sobrah yang dipakai di kepala oleh dalang topeng pada saat melaksanakan pertunjukan tari topeng Cirebon, ternyata mempunyai makna yang dalam. Sobrah yang mirip dengan mahkota, terutama dikenakan oleh raja-raja atau para ratu kerajaan dahulu, memiliki simbol tari topeng yang diperagakan oleh kalangan ningrat atau 
orang yang memiliki status kedudukan yang tinggi dalam kelompok masyarakat tertentu. Lebih dari itu, sobrah merupakan suatu makna yang diartikan sebagai kesabaran dan ketabahan seorang manusia dalam mengarungi kehidupan yang penuh dengan lika-likunya. Sobrah ini terbuat dari rambut dan berwarna hitam. Adapun rumbai-rumbai yang masih bagian dari sobrah, terdapat di kanan dan kiri, memiliki arti sebagai suatu kehidupan yang kompleks dan harus dilalui dengan penuh kesabaran dalam menjalaninya. Hal tersebut dinyatakan dalam ungkapan "kata sobrah berasal dari kata sobru dalam bahasa Al-Qur'an yang artinya sabar. Dalam pertunjukan topeng, khususnya topeng Panji kita diajak untuk berprilaku sabar, tidak cepat menyerah, atau putus asa”. (Kartika, 1999:47).

Kita teringat dengan warna hitam dari sobrah, yakni serupa dengan Ka'bah dan batu Hajar Aswad di Mekkah. Warna hitam ternyata melambangkan keabadian, kelanggengan, karena warna hitam dalam Ka'bah dan batu Hajar Aswad hingga kini tidak pernah luntur sedikit pun. Itulah kiranya, sobrah pun akan tetap ada dalam busana topeng Cirebon, khususnya Panji sebagai bentuk kelanggengan kesenian ini.

\section{Kesimpulan}

Dari keempat topeng Cirebon lainnya (Pamindo, Rumyang, Tumenggung, dan Klana), Panji memiliki keunikan tersendiri. Topeng keempat lainnya, selain Panji, dianggap biasa-biasa saja. Artinya, dari segi gerakan dan musiknya tidak terdapat unsur yang unik. Gerakan dan musiknya, serasi, jika tempo musiknya cepat, maka gerakannya pun gesit. Sebaliknya, jika tempo musiknya rendah, maka gerakannya pun lambat. Hal ini tidak terjadi di dalam tari topeng Panji. Topeng Panji memiliki hal yang istimewa, yakni jika dilihat dari segi gerakannya sangat berlawanan dengan irama musiknya. Irama musiknya yang cepat, namun gerakannya terkesan lambat, statis dan minimalis. Hal ini, membuat para penari atau dalang topeng sangat sulit mempelajari tari topeng Panji tersebut. Dalam topeng Cirebon, tari Panji berada pada urutan pertama dalam suatu pementasan. Namun, dipelajari pada tahap akhir, karena tingkat kesulitannya yang tinggi. Tidak banyak dalang topeng yang bisa menarikan topeng Panji. Sebut saja Sujana Ardja, Keni, Rasinah yang mahir dalam menarikan topeng Panji.

Topeng Panji Cirebon dimaknai sebagai manusia Insan Kamil yang telah berada pada tingkat ma'rifat. Ma'rifat merupakan tingkatan tertinggi dalam kehidupan manusia. Kehidupan yang ma'rifat akan dicapai manakala manusia telah memiliki sifat penyabar, dan pandai bersyukur. Tindak-tanduknya mencerminkan seorang yang memiliki 
sifat luhur. Ia tidak mempunyai sifat dendam, iri hati, dengki, sombong dan tamak. Sebaliknya, manusia ma'rifat selalu tersenyum dalam keadaan apa pun, karena ia telah pasrah terhadap ketentuan Tuhan Yang Maha Kuasa.

\section{DAFTAR PUSTAKA}

Mulyana, Deddy. 2002. Ilmu Komunikasi Suatu Pengantar. Bandung: Remaja Rosdakarya.

Mulyana, Deddy dan Solatun. 2007. Metode Penelitian Komunikasi. Bandung: Remaja Rosdakarya.

Murgiyanto, Sal. 1980. Analisis Kebudayaan. Jakarta: Departemen Pendidikan dan Kebudayaan.

P. Spradley, James. 2007. The Ethnographic Interview. Terjemahan Misbah Zulfa Elizabeth. Edisi kedua. Yogyakarta. Tiara Wacana.

Santi, Kartika Jamilah. 1999. Makna Topeng Panji Gaya Slangit Dalam Topeng Cirebon. Bandung: Sekolah Tinggi Seni Indonesia.

Suanda, Amsar Toto. 1989. "Tari Topeng Panji Sebagai Tari Meditasi." Bandung: Akademi Seni Tari Indonesia.

Sumardjo, Jakob. 2000. Filsafat Seni. Bandung: ITB.

Suryaatmadja, Maman. 1980.“Topeng Cirebon Dalam Perkembangan Penyebaran Serta Peranannya dalam Masyarakat Jawa Barat, Khususnya di Daerah Cirebon". Bandung: Akademi Seni Tari Indonesia 